\title{
Anomalous Lobar Pattern of Right Lung: A Case Report
}

\author{
Anomalía del Patrón Lobar del Pulmón Derecho: Reporte de un Caso \\ "Vishal Modgil; "
}

\begin{abstract}
MODGIL, V.; DAS, S. \& SURI, R. Anomalous lobar pattern of right lung: A case report. Int. J. Morphol., 24(1):5-6, 2006.
SUMMARY: The right lung classically has two fissures, an oblique and a horizontal, dividing it into three lobes namely the superior, middle and lower. The anomaly of the lobar pattern has been described by many research workers on CT scans, where as, there are fewer studies on gross anatomical specimens. In the present case, which was incidentally detected, we report three fissures dividing the right lung into four lobes. Such abnormal fissures and lobes are clinically important for identifying broncho-pulmonary segments. Anatomical knowledge of anomalies of fissures and lobes of lungs may be important for surgeons performing lobectomies, radiologists interpreting X ray and CT scans and also of academic interest to all medical personnel.
\end{abstract}

KEY WORDS: Anomaly; Anatomical variation; Abnormal; Fissure; Lobe; Lung.

\section{INTRODUCTION}

The anatomical knowledge of the fissures and the lobes of the lung is important for accurate interpretation on CT scans. The right lung classically has two fissures, an oblique and a horizontal dividing it into three lobes namely the superior, middle and lower (Standring, 2005). The oblique fissure runs downwards, thereby meeting the inferior border of the lung at a distance of approximately $7.5 \mathrm{~cm}$ behind anterior end (Standring). In the present case we report an accessory fissure in the right lung specimen which divided it into four lobes.

The horizontal fissure is reported to pass from the oblique fissure at the level of midaxillary line to the anterior border of the lung at the level of sternal end of fourth costal cartilage (Standring). The present case describes a peculiar horizontal fissure which started from the oblique fissure but traversed backwards towards the vertebral part of the medial surface.

The knowledge of anatomical variations of the lobes of the lung is important for identifying broncho-pulmonary segments. Many a times, radiologists may misinterpret an X ray or CT scan. Anatomical knowledge of such variations is helpful for lobectomies and surgical resections involving individual segments.

\section{CASE REPORT}

During routine dissection of thoracic region of 45 year old male cadaver, we encountered an anomalous right lung, which displayed variation in the pattern of fissures and lobes. There was no history of pulmonary disease in the individual. The pulmonary fissures and lobes were studied and appropriate measurements were taken. The specimen was photographed (Fig.1).

\section{OBSERVATIONS}

The right lung displayed an oblique fissure, which originated at a distance of $7 \mathrm{~cm}$ from the apex on the vertebral part of medial surface and after traversing a distance of $8 \mathrm{cms}$, it further sub divided into two fissures. One of the fissures continued towards the anterior border to cross it at a distance of $13 \mathrm{cms}$ from the apex (horizontal fissure). The other fissure continued downwards as the conventional oblique fissure to cross the inferior border at a distance of 2 $\mathrm{cm}$ from the anterior border. An accessory fissure was noted in the superior segment of the inferior lobe. As a consequence to anomalous fissure, we observed four lobes in the right lung. No abnormality was detected in the left lung.

\footnotetext{
* Senior Resident, Department of Anatomy, Maulana Azad Medical College,New Delhi-110002, India

** Associate Professor, Department of Anatomy, Maulana Azad Medical College, New Delhi-110002, India.

${ }^{* * *}$ Professor, Department of Anatomy, Maulana Azad Medical College, New Delhi-110002, India.
} 
Fig.1. Photograph of dissected right lung specimen showing:

A. Oblique fissure;

B. Horizontal fissure;

C. Accessory fissure;

D. Apex; E. Base.

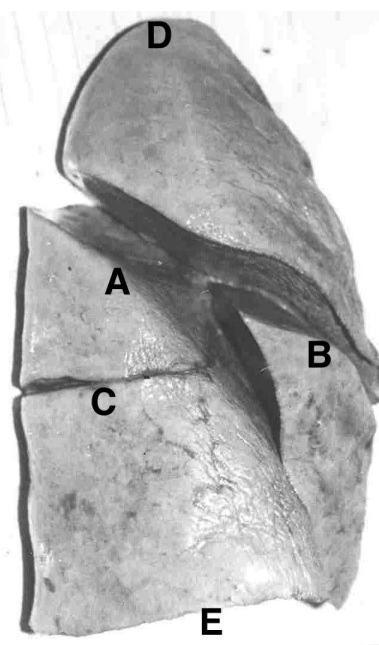

\section{DISCUSSION}

The defective pulmonary development gives rise to variations in lobes and fissures of lung. The fissures are the spaces which separate individual broncopulmonary buds or segments and they get obliterated except along the two planes which later manifests as horizontal or oblique fissure (Meenakshi, 2004). Non-obliteration of these spaces gives rise to accessory fissures of the lung (Meenakshi). An accessory fissure may be of varying depth occurring between bronco-pulmonary segment (David \& Tarver, 1984). Accessory fissures may be present in any of the five lobes. The inferior accessory fissure which demarcates the medial basal segment and the superior fissure which demarcates the superior segment, are the most common accessory fissures detected on CT scans (David \& Tarver).

The accessory fissure which separates the superior segment of the lower lobe from the basal segment is termed as 'superior accessory fissure' (David \& Tarver). In the present study, the accessory fissure detected on the right lung can be correctly termed as superior accessory fissure.
The incidence of superior accessory fissure is reported to be more common in the right lung as compared to the left one (David \& Tarver). The present finding agrees to this fact. Interestingly, superior accessory fissure has a reported incidence of 5-30\% in autopsy studies as compared to $3 \%$ incidence in high resolution CT scans hence the knowledge of its presence is clinically important for correct interpretation of CT scans (David \& Tarver).

Knowledge of an accessory fissure is helpful for clinicians in order to differentiate it from other normal anatomical and pathological structures. Interpretation of various radiographic appearances of interlobar fluid is important for clinicians. In X ray, incomplete fissures always give an atypical appearance of pleural effusion. Many a times, the accessory fissures fail to be detected on CT scans, because of their incompleteness, thick sections and orientation in relation to a particular plane (Ariyurek, 2001).

In many diseases, segmental localization is a must and the knowledge of accessory fissure is of much clinical importance to the clinician. Pre operative planning and strategy for pulmonary lobectomy and segmental resection may also change during presence of such accessory fissures. An incomplete fissure is also a cause for post operative air leakage (Walker, 1997). Often this accessory fissure acts as a barrier to infection spread, creating a sharply marginated pneumonia which can wrongly be interpreted as atelectasis or consolidation (Godwin \& Tarver). Incomplete fissures are also responsible for altering the spread of any lung disease. (Meenakshi).

The knowledge of anatomy of fissures of lung may help clarifying initially confusing radiographic findings like extension of fluid into an incomplete major fissure or spread of various diseases through different pathways (Dandy, 1978). Considering the clinical importance of such anomalies, we as anatomists opine that prior awareness and anatomical knowledge of the presence of accessory fissures and lobes in the lung may be important for clinicians and radiologists.

MODGIL, V.; DAS, S. \& SURI, R. Anomlía del patrón lobar del pulnón derecho: Reporte de un caso. Int. J. Morphol., 24(1):5-6, 2005.

RESUMEN: El pulmón derecho clásicamente tiene dos fisuras, una oblicua y una horizontal, dividiéndolo en tres lóbulos: superior, medio e inferior. Anomalías del patrón lobar han sido descritas en algunas investigaciones con scaner, pero son poco estudiadas en anatomía macroscópica. En el presente caso, el cual fue accidentalmente detectado, describimos tres fisuras dividiendo el pulmón derecho en cuatro lóbulos. Tanto las fisuras como los lóbulos son clínicamente importantes para identificar segmentos broncopulmonares. El conocimiento de las variaciones de las fisuras y de los lóbulos del pulmón son importantes para los cirujanos, imagenólogos y anatomistas.

PALABRAS CLAVE: Anomalía; Variación anatómica; Fisura; Lóbulo; Pulmón.

\section{REFERENCES}

Ariyurek, O. M.: Gulsun, M. \& Demirkazik, F. B. Accessory fissures of the lung: evaluation by high-resolution computed tomography. Eur. Radiol., 11:2449-53, 2001.

Dandy, W. E. Incomplete pulmonary interlobar fissure sign. Radiology, 128:21-5, 1978.

Godwin, J. D. \& Tarver, R. D. Accessory Fissures of the Lung. A. J. R., 144:39-47, 1984.

Meenakshi, S.; Manjunath, K.Y. \& Balasubramanyam, V. Morphological Variations of the Lung Fissures and lobes. The Indian J. of Chest Diseases \& Allied Sciences., 46: 179-82, 2004.
Standring S. Gray's Anatomy. 39th ed. Churchill Livingstone, New York, 2005. pp. 947.

Walker, W. S. \& Craig, S. R. A proposed anatomical classification of the pulmonary fissures. J. R. Coll. Surg. Edinburg., 42:233-4, 1997.

Correspondence to:

Dr. Srijit Das

190 RPS Flats

Sheikh Sarai Phase-I

New Delhi-110017

$I \mathcal{N D I A}$

E-mail: das_srijit23@rediffmail.com

Received: 03-09-2005

Accepted: 24-10-2005 